\title{
Phytochemical and Antifungal Efficacy of Leaf and Stem Bark Extracts of Parkia biglobosa on Fungi Associated with Seed Rot of Green Bean (Phaseolus vulgaries L.) in Akpabuyo, Cross River State, Nigeria
}

\author{
*Akwaji, Patrick Ishoro', Okon, Ekeng Ita ${ }^{1}$, Umana, Etim Johnson ${ }^{1}$ \\ and Markson, Aniedi-Abasi Akpan ${ }^{1}$ \\ 1. Department of Botany, University of Calabar, Calabar, \\ Cross River State, Nigeria.
}

Corresponding Author: akwajiisnever@yahoo.com

Keywords: Phytochemical, antifungal, extracts, green bean, seed rot, fungal pathogens

\begin{abstract}
The phytochemical and antifungal efficacy of the ethanolic and methanolic stem bark and leaf extracts of Parkia biglobosa on the fungal pathogens isolated from infected green bean seeds obtained from the field in Akpabuyo, Cross River State, Nigeria were investigated in vitro. The pathogens were Botryodiplodia theobromae and Aspergillus niger. Various concentrations of the extracts ranging from $10 \mathrm{~g} / 100 \mathrm{ml}, 20 \mathrm{~g} / 100 \mathrm{ml}, 30 \mathrm{~g} / 100 \mathrm{ml}, 40 \mathrm{~g} / 100 \mathrm{ml}$ and $50 \mathrm{~g} / 100 \mathrm{ml}$ were separately added to PDA media. Results of the in vitro antifungal assay shows that at $40 \mathrm{~g} / 100 \mathrm{ml}$ and $50 \mathrm{~g} / 100 \mathrm{ml}$ concentrations, ethanolic stem bark and leaf extracts of P. biglobosa completely inhibited the radial growth of $B$. theobromae and $A$. niger after seven days observation period while those of methanolic extracts completely inhibited the redial growth of the fungal pathogens at $50 \mathrm{~g} / 100 \mathrm{ml}$ concentration. Results, however, shows that the extracts had a significant effect $(\mathrm{P} \leq 0.05)$ on the radial growth of the fungal pathogens at all the different concentrations tested as compared with the control. Pathogen growth inhibition was most effective at $30 \mathrm{~g} / 100 \mathrm{ml}, 40 \mathrm{~g} / 100 \mathrm{ml}$ and $50 \mathrm{~g} / 100 \mathrm{ml}$ concentrations. The inhibitory action of the extracts increased/decreased with a corresponding increase/decrease in the concentration of the plant extracts. Ethanolic stem bark and leaf extracts of P. biglobosa was found to be more effective in inhibiting the redial growth of the fungal pathogens than those of methanolic extracts, also ethanolic and methanolic stem bark extracts were observed to be more effective in the inhibition of the radial growth of the fungal pathogens than leaf extracts. Phytochemical screening of the extracts revealed the presence of cardiac glycosides, reducing sugars, flavonoids, saponnins and tannins with traces of alkaloids in stem bark extracts while flavonoids, alkaloids, cardiac glycosides, saponnins, tannins and terpenoids were present in leaf extracts.
\end{abstract}

\section{INTRODUCTION}

Green bean (Phaseolus vulgaris L.), family Fabaceae is a major grain legume that is consumed worldwide for its edible grains and pod. Phaseolus vulgaris is an herbaceous annual plant. It is a climbing vine that grows up to $2-5 \mathrm{~m}$ long [1]. It represents a great source of nutrition for millions of people and is second most important legume crop after soybean [1].

[2], documented that green bean is cultivated as a major food crop in many tropical, subtropical and temperate areas of Americas, Europe, Africa and Asia. It grows well on soils with $\mathrm{pH}$ ranging from 4-9. It does better on well-drained, sandy loam, silt loam or clay loams, which are rich in inorganic content [3]. The leaf is occasionally used as a leaf vegetable and the straw used for folder [3]. Green bean is one crop that cannot withstand water-logging though some cultivars do well in standing water [2].

Green bean is grown and consumed principally in developing countries in Latin America (with Brazil and Mexico as the most important producers), Eastern Africa (where per capita consumption is the highest in the world in countries such as Burundi, Rwanda and Uganda) [4], and in Asian countries such as China and Myanmar. Phaseolus vulgaris is an important dietary component in Nigeria. For countries such as Brazil and Mexico, it is a major source of protein. 
Daily intake of total protein in some of the least developed countries, such as Burundi, Rwanda and Uganda, is $40 \%, 31 \%$ and $15 \%$ respectively [5]. For other developing countries, the total protein derived from common bean is Nicaragua (19\%), Cuba (13\%) and North Korea (11\%). For a major producer like Brazil, P. vulgaris provide $9 \%$ of protein. It has been reported that bean seed proteins provide sulfur essential amino acids such as lysine, but poor in methionine, thus complementing cereal in this respect [5]. Beans are also a major source of calories for residents of these countries. In addition, common bean plays an important role as a source of minerals especially iron and zinc $[3,4]$, for which it also complement cereals.

The green bean is a highly variable species with a long history. Bush varieties form erect bushes $20-50 \mathrm{~cm}(8-20 \mathrm{in})$ tall, while pole or running varieties form vines 2-3 $\mathrm{m} \mathrm{(7-10} \mathrm{ft)} \mathrm{long.} \mathrm{All}$ varieties bear alternate, green or purple leaves, which are divided into three oval, smooth-edged leaflets, each 6-15 cm (2-6 in) long and 3-11 cm (1-4 in) wide. The white, pink, or purple flowers are about $1 \mathrm{~cm}$ long, and they give way to pods $8-20 \mathrm{~cm}(3-8 \mathrm{in})$ long and 1-1.5 $\mathrm{cm}$ wide. These may be green, yellow, black, or purple in color, each containing 4-6 beans. The beans are smooth, plump, and kidney-shaped, up to $1.5 \mathrm{~cm}$ long, range widely in color, and are often mottled in two or more colors [4].

Green beans are rich in protein $(22-27 \%)$ and starch $(39-47 \%)$ and relatively low in fibre (crude fibre $<6 \%$ ), making them a potentially valuable ingredient in all livestock species. However, the presence of anti-nutritional factors degrades their potential feeding value, notably for monogastric animals [6]. The composition of bean crop residues depends on the proportions of stems, pod husks and leaves: stems and pod husks have a low protein content (8\% and 4\% respectively) while the leaves are much richer in protein $(20 \%)$ [7], green bean straw (haulms) contains about $5-11 \%$ of protein and is rich in fibre (crude fibre $38-45 \%$ ). However, like other legume straws, it has a better nutritive value than cereal straws due to high protein content and lower fibre content though the composition is variable: for instance, stem-rich bean straw was reported to contain $61 \%$ vs $51 \%$ for a leaf-rich straw [7].The green bean plant is of minor importance as fodder in ruminant feeding, however, the beans, straw and other crop residues and processing by-products are occasionally used. It is the most important source of plant protein in human food.

Several fungi attack on the plant during growth, harvest and storage. While more than 25 different species of fungi are known to invade stored grains [8], species of Aspergillus, Penicillum and Fusarium are responsible for most spoilage and germ damage in storage [9]. They cause reduction in cooking and baking quality, and nutritive values, produce undesirable odors and color, and change appearance of stored food grains, decrease germinability and total decay [9, 10]. In addition, they produce mycotixins which pose health hazard for man and animals, make products unacceptable for edible purposes or lower their market grade. Moreover, fungal infection of seed coat decreases viability of seeds, or may cause abnormal seedlings [11].

A large number of fungal species are regularly associated with seeds and can infect developing seeds still attached to the mother plant $[12,13]$. This has been demonstrated by the isolation of fungi from seeds collected before seed-set.

Due to complaints received from farmers in Akpabuyo Local Government Area, Cross River State, Nigeria on the menace caused by rot disease of green bean seeds in farms where there are grown and the observed disease incidence/severity, and in view of the role played by this plant in generating income and providing a means of livelihood for the farmers. It became necessary to isolate and identify the causative agents of the infection and to find out a better control measure that is environmentally friendly such as the use of plant extracts to control the infection.

\section{MATERIALS AND METHODS}

\section{Collection of materials}

Stem bark and leaves of Parkia biglobosa were obtained from the wild in Ogoja, Northern Cross River State, Nigeria and used for the preparation of extracts. Healthy and infected green beans seeds 
were obtained from different farms in Akpabuyo Local Government Area of Cross River State, Nigeria. The experiment was carried out in the Department of Botany, University of Calabar, Calabar, Cross River State, Nigeria.

\section{Isolation of fungal pathogens and morphological identification}

Diseased assay seeds were surface sterilized with 70\% Sodium hypochlorite solution for $1 \mathrm{~min}$ and rinsed quickly in three (3) changes of sterile distilled water, blotted dry on Whatman's No. 1filter paper and placed on Potato Dextrose Agar (PDA) in Petri dishes. Four (4) sections were inoculated per Petri dish. The plates were incubated at $28 \pm 1{ }^{\circ} \mathrm{C}$ until fungal growth was noticed. After 5 days, the different isolates were sub-cultured on freshly prepared PDA to obtain their pure culture. Isolated fungi were microscopically (Olympus optical, Phillipines) identified as far as possible using the identification guides of the International Mycological Institute, Kew and of $[14,15]$.

\section{Pathogenicity Test}

Pathogenicity test was ascertained using Koch's postulates. To test pathogenicity of the isolated fungal pathogens, some pieces of spores were re-inoculated into matured healthy green bean seeds. The healthy green bean seeds were washed with distilled water and surface sterilized with 99\% ethanol. For the spore inoculation, a spore suspension was produced using the method of [16]. With a sterilized hypodermic needle, approximately $2 \times 10-5$ spore was inoculated on the green bean seeds by spraying to run-off level. The green bean seeds was put into transparent polyethylene bags and allowed to stay for 24hours. Spores measurement was done with a haemocytometer. The control experiment was carried out with sterile distilled water without spores. All the experimental setup was observed for symptom development. The experiment was carried out in three replicates.

\section{Preparation of plant materials}

Stem bark and leaf of Parkia biglobosa used in the study were separately washed thoroughly using distilled water and surface sterilized with $99 \%$ ethanol and sun-dried for 6 days. The dried plant stem bark and leaves were blended separately using a sterile electric blender to obtain 200 grams of fine powder of each sample.

\section{Methanolic extracts}

Methanolic extracts of stem bark and leaf were obtained by adding the dried powder (blended) of plant materials to methanol at room temperature $28 \pm 1{ }^{\circ} \mathrm{C}$. Five levels of concentrations were obtained by dissolving $10 \mathrm{~g}, 20 \mathrm{~g}, 30 \mathrm{~g}, 40 \mathrm{~g}$ and $50 \mathrm{~g}$ of each sample with $100 \mathrm{ml}$ of methanol. This was vigorously stirred and allowed for 24 hours. The solution was then filtered through four-folds of sterile cheese cloth for all the plant materials. The filtrates obtained were used as methanolic extracts of the test plants and stored in reagent bottles for further use.

\section{Ethanolic extracts}

Ethanolic extracts of plant materials were obtained by adding the powdered sample at different concentrations, $10 \mathrm{~g}, 20 \mathrm{~g}, 30 \mathrm{~g}, 40 \mathrm{~g}$ and $50 \mathrm{~g}$ to $100 \mathrm{mls}$ of ethanol. This was stirred vigorously and allowed for 24 hours at room temperature $28 \pm 1{ }^{\circ} \mathrm{C}$. The solution was then filtered through four-folds of sterile cheese cloth for all the plant materials. The filtrates obtained were used as ethanolic extracts of the test plants and stored in reagent bottles for further use.

\section{Susceptibility test}

The extracts percentage concentrations were prepared at $10 \mathrm{~g} / 100 \mathrm{ml}, 20 \mathrm{~g} / 100 \mathrm{ml}, 30 \mathrm{~g} / 100 \mathrm{ml}$, $40 \mathrm{~g} / 100 \mathrm{ml}$ and $50 \mathrm{~g} / 100 \mathrm{ml}$ with ethanol and methanol as solvent.

\section{Test dilution method}

$5 \mathrm{ml}$ of each concentration of both the ethanolic and methanol stem bark and leaf extracts of Parkia biglobosa was first poured into different Petri-dishes using sterile syringe. The sterile Potato Dextrose Agar (PDA) was also poured into the plates containing the solvent extracts after which the plates containing the solvent extracts were gently swirled to ensure mixing. The media was allowed 
to solidify and with a sterilized cork borer ( $5 \mathrm{~mm}$ in diameter), a disc of the matured culture was punched out from advancing margin of a four- day old pure culture and inoculated at the center of plates and incubated at room temperature $(28 \pm 10 \mathrm{c})$ for 7 days. The experiment was replicated thrice. Area of inhibition was measured daily for 7 days using a meter rule and recorded.

\section{Phytochemical Screening}

Phychemical screening of the ethanolic and methanolic extracts of stem bark and leaf of Parkia biglobosa was carried out using the methods of $[17,18,19]$. Phytochemical screening was carried out in the Department of Biochemistry, University of Calabar, Calabar, Cross River State, Nigeria.

\section{Test for Tannin}

Plant extract (about $1.0 \mathrm{~g}$ ) was stirred with sterile distilled water $(10 \mathrm{ml})$ and filtered (using Whatman's no. 1 filter paper). A blue colouration resulting from the addition of 2 drops of $10 \%$ $\mathrm{FeCl}_{3}$ reagent to the filtrate indicated the presence of tannins.

\section{Test for Alkaloids}

One half of a gram of the plant extract was dissolved in $1 \% \mathrm{Hcl}(5 \mathrm{ml})$ on a steam bath. The filtrate $(1 \mathrm{ml})$ was treated with few drops of Dragendorff's reagent (Potassium iodide $0.11 \mathrm{M}$, Bismuth nitrate $0.6 \mathrm{M}$ in Acetic acid $3.5 \mathrm{M}$ ). Turbidity or precipitation was taken as indicative of the presence of alkaloids.

\section{Test for Tannin}

Plant extract (about $1.0 \mathrm{~g}$ ) was stirred with sterile distilled water $(10 \mathrm{ml})$ and filtered (using Whatman's no. 1 filter paper). A blue colouration resulting from the addition of 2 drops of $10 \%$ $\mathrm{FeCl}_{3}$ reagent to the filtrate indicated the presence of tannins.

\section{Test for Flavonoids}

An aliquot of the extract ( $0.2 \mathrm{~g})$ was dissolved in ethanol and methanol $(2 \mathrm{ml})$ and heated. A chip of magnesium metal strip was added to the mixture followed by the addition of a few drops of concentrated Hcl. The occurrence of a red or orange colouration was indicative of the presence of flavonoids.

\section{Test for Saponins}

Powdered sample (about $2 \mathrm{~g}$ ) was boiled in distilled water $(20 \mathrm{ml})$ in a water bath and then filtered. The filtrate $(10 \mathrm{ml})$ was mixed with distilled water $(5 \mathrm{ml})$ and shaken vigorously to form a stable persistent froth. The froth was mixed with 3 drops of olive oil, shaken vigorously, and then observed for the formation of emulsions.

\section{Test for Steroids}

The extract (about $0.5 \mathrm{~g}$ ) was dissolved in $\mathrm{CHCl}_{3}(3 \mathrm{ml})$ and then filtered. To the filtrate was added concentrated $\mathrm{H}_{2} \mathrm{SO} 4$ to form a lower layer. A reddish brown colour was taken as positive for steroids.

\section{Test for Reducing Sugars}

One millilitre each of Fehling's solutions I and II was added to an aqueous solution of the extract $(2 \mathrm{ml})$. The mixture was heated in a boiling water bath for about $2-5 \mathrm{~min}$. The production of a brick red precipitate indicated the presence of reducing sugars.

\section{Test for Anthraquinones}

A sample of plant extract $(0.5 \mathrm{~g})$ was boiled with $0.01 \mathrm{M} \mathrm{Hcl}$ and filtered while still hot. The filtrate was shaken with benzene $(10 \mathrm{~mL})$. The benzene layer was removed, and ammonium hydroxide $(5 \mathrm{ml}, 10 \%)$ was added. A violet, red, or pink colouration in the ammonia phase is positive for anthraquinones. 


\section{Test for Cardiac Glycosides}

The extract (about $0.5 \mathrm{~g}$ ) was dissolved in glacial acetic acid $(2 \mathrm{ml})$ containing 1 drop of $1 \% \mathrm{FeCl}_{3}$. This was under laid with concentrated $\mathrm{H}_{2} \mathrm{SO} 4$. A brown ring at the interface indicated the presence of a deoxygenated sugar, characteristic of cardiac glycosides. A violet ring may form just above ring and gradually spreads through this layer.

\section{RESULTS}

\section{Isolated fungal pathogens}

The fungal pathogens isolated and identified as the causative agents of seed rot of green bean from this study were: Botryodiplodia theobromae (Figure 1) and Aspergillus niger (figure 2).

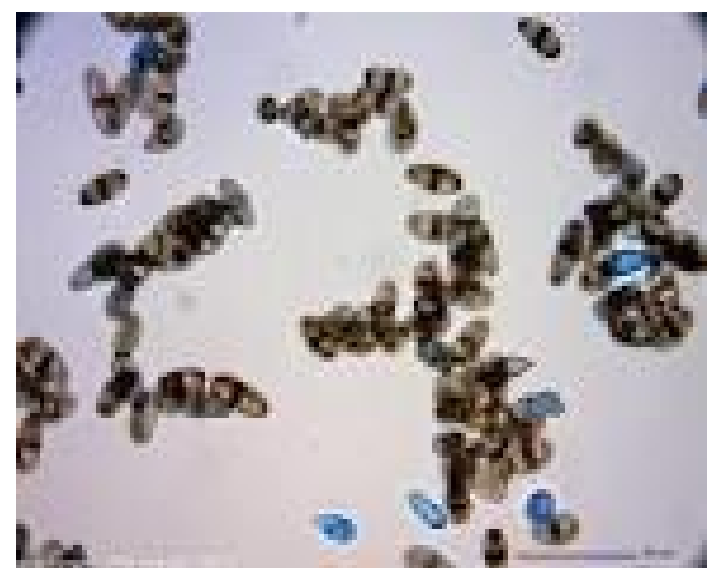

Figure 1

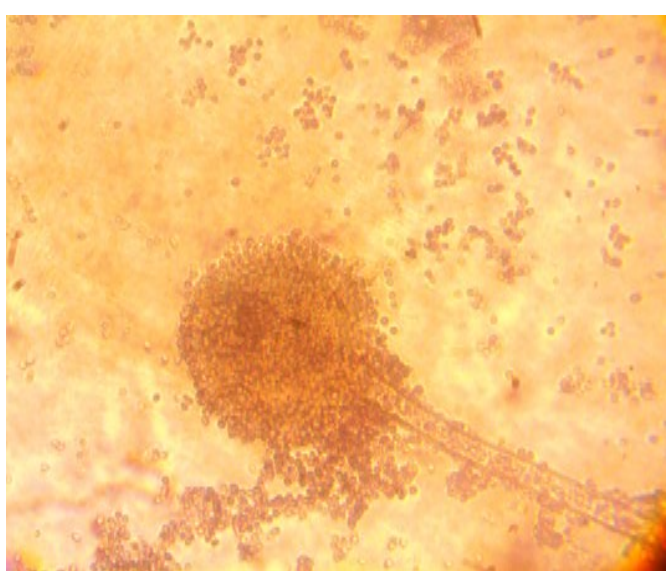

Figure 2

Figure 1: Photomicrograph of Botryodiplodia theobromae $\times 100$ showing the broken mycelium/hyphae and

Figure 2: Photomicrograph of Aspergillus niger $\times 40$ showing the macro and micro conidia

\section{Pathogenicity Test}

Symptoms observed on the seeds inoculated with Botryodiplodia theobromae and Aspergillus niger were similar to those observed on the rotted seeds obtained from the field. Symptoms such as soft and dry rots were observed on the seeds.

\section{Phytochemical screening}

Phytochemical screening of the ethanolic and methanolic extracts of stem bark and leaf of P. biglobosa showed that cardiac glycosides, flavonoids, saponins, reducing sugars and tannins were highly present in the ethanolic stem bark extract while alkaloids and steroids was slightly present. Phlobatannins and terpenoids were absent. Flavonoids, saponnins, tannins, cardiac glycosides and terpenoids were highly present in the ethanolic leaf extracts while alkaloids were slightly present. Anthraquinones, steroids, reducing sugars and phlobatannins were absent. Phytochemical constituents of methanolic extracts of stem bark and leaf of P. biglobosa showed that flavonoids, saponnins, tannins, cardiac glycosides and reducing sugars were present while terpenoids were slightly present. Alkaloids, anthraquinones, steroids and phlobatannins were absent. Flavonoids, saponnins, tannins and cardiac glycosides were present in methonolic leaf extracts while alkaloids and terpenoids were slightly present. Anthraquinones, steroids, reducing sugars and phlobatannins were absent as presented in (Table 1). 
Table 1: Phytochemical constituents of ethanolic and methanolic stem bark and leaf extracts of Parkia biglobosa

\begin{tabular}{lllll}
\hline $\begin{array}{l}\text { Phytochemical } \\
\text { constituents }\end{array}$ & $\begin{array}{l}\text { Ethanol } \\
\text { extract (stem } \\
\text { bark) }\end{array}$ & $\begin{array}{l}\text { Ethanol } \\
\text { extract } \\
\text { (leaf) }\end{array}$ & $\begin{array}{l}\text { Methanol } \\
\text { extract } \\
\text { (stem } \\
\text { bark }\end{array}$ & $\begin{array}{l}\text { Methanol } \\
\text { extract } \\
\text { (leaf) }\end{array}$ \\
\hline Flavonoids & +++ & +++ & ++ & ++ \\
saponins & +++ & +++ & ++ & ++ \\
Tannins & +++ & +++ & ++ & ++ \\
Alkaloids & + & + & - & + \\
Anthraquinones & - & - & - & - \\
Cardiac glycosides & +++ & +++ & ++ & ++ \\
Steroids & + & - & - & - \\
Reducing sugars & +++ & - & ++ & - \\
Phlobatannins & - & - & - & - \\
Terpenoids & - & +++ & + & + \\
\hline
\end{tabular}

Note: $(+++)=$ highly present, $(++)=$ present, $(+)=$ slightly present, $(-)=$ absent

In vitro effect of ethanolic stem bark and leaf extracts of Parkia biglobosa on Botryodiplodia theobromae and Aspergillus niger at the different concentrations.

The in vitro effect of the ethanolic extracts of stem bark and leaf of P. biglobosa at the different concentrations on the radial growth of B. theobromae and A. niger is presented in (Tables 2 and 5). Results from the study showed that ethanolic extracts of stem bark and leaf of P. biglobosa had a significant effect on the isolated fungal pathogens at all levels of concentration $(10 \mathrm{~g} / 100 \mathrm{ml}$, $20 \mathrm{~g} / 100 \mathrm{ml}$ and $30 \mathrm{~g} / 100 \mathrm{ml}, 40 \mathrm{~g} / 100 \mathrm{ml}$ and $50 \mathrm{~g} / 100 \mathrm{ml})$ tested as compared with the control. Results (Table 2 and 5) showed that ethanolic extracts of stem bark and leaf of P.biglosa at $40 \mathrm{~g} / 100 \mathrm{ml}$ and $50 \mathrm{~g} / 100 \mathrm{ml}$ concentrations completely inhibited the radial growth of $B$. theobromae and $A$. niger in the first to seventh day of incubation and at $10 \mathrm{~g} / 100 \mathrm{ml}$ concentration on the first to third and fourth day of incubation respectively while at $20 \mathrm{~g} / 100 \mathrm{ml}$ and $30 \mathrm{~g} / 100 \mathrm{ml}$ concentrations, the radial growth of $B$. theobromae and A. niger was mostly inhibited throughout the incubation period as compared with the control. It is worthy of note to state that results shows that the ethanolic stem bark extracts of $P$. biglobosa was more effective in inhibiting the growth of the fungal pathogens than the leaf extracts when compared with the control. The radial growth of the fungal pathogens also decreased with a corresponding increase in the concentration of the extracts.

Table 2: In vitro effect of ethanolic Parkia biglobosa stem bark extract on the radial growth of Botryodiplodia theobromae.

\begin{tabular}{llllllll}
\hline Concentration & \multicolumn{7}{l}{ Days of incubation and radial growth $\left(\mathbf{c m}^{2}\right)$} \\
\hline $10 \mathrm{~g} / 100 \mathrm{ml}$ & $\mathbf{1}$ & $\mathbf{2}$ & $\mathbf{3}$ & $\mathbf{4}$ & $\mathbf{5}$ & $\mathbf{6}$ & $\mathbf{7}$ \\
$20 \mathrm{~g} / 100 \mathrm{ml}$ & 0.00 & 0.00 & 0.00 & 1.00 & 1.20 & 1.30 & 1.31 \\
$30 \mathrm{~g} / 100 \mathrm{ml}$ & 0.00 & 0.00 & 0.00 & 0.00 & 0.00 & 1.00 & 1.14 \\
$40 \mathrm{~g} / 100 \mathrm{ml}$ & 0.00 & 0.00 & 0.00 & 0.00 & 0.00 & 0.00 & 1.00 \\
$50 \mathrm{~g} / 100 \mathrm{ml}$ & 0.00 & 0.00 & 0.00 & 0.00 & 0.00 & 0.00 & 0.00 \\
\hline Control & 0.00 & 0.00 & 0.00 & 0.00 & 0.00 & 0.00 & 0.00 \\
\hline
\end{tabular}


Table 3: In vitro effect of ethanolic Parkia biglobosa leaf extract on the radial growth of Aspergillus niger (cm).

\begin{tabular}{llllllll}
\hline Concentration & \multicolumn{7}{l}{ Days of incubation and radial growth $\left(\mathbf{c m}^{2}\right)$} \\
\hline $10 \mathrm{~g} / 100 \mathrm{ml}$ & $\mathbf{1}$ & $\mathbf{2}$ & $\mathbf{3}$ & $\mathbf{4}$ & $\mathbf{5}$ & $\mathbf{6}$ & $\mathbf{7}$ \\
$20 \mathrm{~g} / 100 \mathrm{ml}$ & 0.00 & 0.00 & 0.50 & 0.90 & 1.00 & 1.10 & 1.22 \\
$30 \mathrm{~g} / 100 \mathrm{ml}$ & 0.00 & 0.00 & 0.00 & 0.96 & 1.00 & 1.00 & 1.10 \\
$40 \mathrm{~g} / 100 \mathrm{ml}$ & 0.00 & 0.00 & 0.00 & 0.00 & 0.50 & 0.90 & 1.00 \\
$50 \mathrm{~g} / 100 \mathrm{ml}$ & 0.00 & 0.00 & 0.00 & 0.00 & 0.00 & 0.00 & 0.00 \\
\hline Control & 0.00 & 0.00 & 0.00 & 0.00 & 0.00 & 0.00 & 0.00 \\
\hline
\end{tabular}

Table 4: In vitro effect of ethanolic Parkia biglobosa stem bark extract on the radial growth of Botryodiplodia theobromae.

\begin{tabular}{llllllll}
\hline Concentration & \multicolumn{7}{l}{ Days of incubation and radial growth $\left(\mathbf{c m}^{\mathbf{2}}\right)$} \\
\hline $10 \mathrm{~g} / 100 \mathrm{ml}$ & $\mathbf{1}$ & $\mathbf{2}$ & $\mathbf{3}$ & $\mathbf{4}$ & $\mathbf{5}$ & $\mathbf{6}$ & $\mathbf{7}$ \\
$20 \mathrm{~g} / 100 \mathrm{ml}$ & 0.00 & 0.00 & 0.00 & 0.00 & 1.00 & 1.00 & 1.16 \\
$30 \mathrm{~g} / 100 \mathrm{ml}$ & 0.00 & 0.00 & 0.00 & 0.00 & 0.00 & 0.00 & 1.00 \\
$40 \mathrm{~g} / 100 \mathrm{ml}$ & 0.00 & 0.00 & 0.00 & 0.00 & 0.00 & 0.00 & 1.00 \\
$50 \mathrm{~g} / 100 \mathrm{ml}$ & 0.00 & 0.00 & 0.00 & 0.00 & 0.00 & 0.00 & 0.00 \\
\hline Control & 0.00 & 0.00 & 0.00 & 0.00 & 0.00 & 0.00 & 0.00 \\
\hline
\end{tabular}

Table 5: In vitro effect of ethanolic Parkia biglobosa leaf extract on the radial growth of Aspergillus niger (cm).

\begin{tabular}{llllllll}
\hline Concentration & \multicolumn{7}{l}{ Days of incubation and radial growth $\left(\mathbf{c m}^{\mathbf{2}}\right)$} \\
\hline & $\mathbf{1}$ & $\mathbf{2}$ & $\mathbf{3}$ & $\mathbf{4}$ & $\mathbf{5}$ & $\mathbf{6}$ & $\mathbf{7}$ \\
$10 \mathrm{~g} / 100 \mathrm{ml}$ & 0.00 & 0.00 & 0.00 & 0.90 & 0.90 & 1.10 & 1.20 \\
$20 \mathrm{~g} / 100 \mathrm{ml}$ & 0.00 & 0.00 & 0.00 & 0.00 & 0.60 & 1.00 & 1.14 \\
$30 \mathrm{~g} / 100 \mathrm{ml}$ & 0.00 & 0.00 & 0.00 & 0.00 & 0.00 & 0.80 & 1.00 \\
$40 \mathrm{~g} / 100 \mathrm{ml}$ & 0.00 & 0.00 & 0.00 & 0.00 & 0.00 & 0.00 & 0.00 \\
$50 \mathrm{~g} / 100 \mathrm{ml}$ & 0.00 & 0.00 & 0.00 & 0.00 & 0.00 & 0.00 & 0.00 \\
\hline Control & 0.70 & 1.60 & 1.90 & 2.70 & 3.00 & 3.20 & 3.50 \\
\hline
\end{tabular}

In vitro effect of methanolic stem bark and leaf extracts of Parkia biglobosa on Botryodiplodia theobromae and Aspergillus niger at the different concentrations.

The in vitro effect of the methanolic stem bark and leaf extracts of $P$. biglobosa at the different concentrations on the radial growth of $B$. theobromae and A. niger is presented in (Tables 6 - 9). Results shows that, at $10 \mathrm{~g} / 200 \mathrm{ml}, 20 \mathrm{~g} / 200 \mathrm{ml}, 30 \mathrm{~g} / 200 \mathrm{ml}, 40 \mathrm{~g} / 200 \mathrm{ml}$ and $50 \mathrm{~g} / 200 \mathrm{ml}$ methanolic extracts of stem bark and leaf of $P$. biglobosa inhibited the radial growth of $B$. theobromae and $A$. niger at the different concentrations tested when compared with the control. Complete inhibition was observed at $50 \mathrm{~g} / 100 \mathrm{ml}$ concentration of methanolic extracts of stem bark and leaf extracts of $P$. biglobosa in the first to sixth and fifth day respectively. It is also worthy of note to state that results shows that the ethanolic extracts of stem bark and leaf of P. biglobosa was more effective in inhibiting the redial growth of $B$. theobromae and $A$. niger than those of the methanolic extracts. 
Table 6: In vitro effect of methanolic Parkia biglobosa stem bark extract on the radial growth of Botryodiplodia theobromae (cm).

\begin{tabular}{llllllll}
\hline Concentration & \multicolumn{7}{l}{ Days of incubation and radial growth $\left(\mathbf{c m}^{\mathbf{2}}\right)$} \\
\hline $10 \mathrm{~g} / 100 \mathrm{ml}$ & $\mathbf{1}$ & $\mathbf{2}$ & $\mathbf{3}$ & $\mathbf{4}$ & $\mathbf{5}$ & $\mathbf{6}$ & $\mathbf{7}$ \\
$20 \mathrm{~g} / 100 \mathrm{ml}$ & 0.00 & 0.00 & 0.92 & 1.10 & 1.10 & 1.26 & 1.30 \\
$30 \mathrm{~g} / 100 \mathrm{ml}$ & 0.00 & 0.00 & 0.00 & 0.60 & 0.80 & 1.10 & 1.25 \\
$40 \mathrm{~g} / 100 \mathrm{ml}$ & 0.00 & 0.00 & 0.00 & 0.00 & 1.00 & 1.16 & 1.10 \\
$50 \mathrm{~g} / 100 \mathrm{ml}$ & 0.00 & 0.00 & 0.00 & 0.00 & 0.00 & 0.00 & 0.72 \\
\hline Control & 0.00 & 0.00 & 0.00 & 0.00 & 0.00 & 0.00 & 1.00 \\
\hline
\end{tabular}

Table 7: In vitro effect of methanolic Parkia biglobosa leaf extract on the radial growth of Aspergillus niger (cm).

\begin{tabular}{llllllll}
\hline Concentration & \multicolumn{7}{l}{ Days of incubation and radial growth $\left(\mathbf{c m}^{\mathbf{2}}\right)$} \\
\hline & $\mathbf{1}$ & $\mathbf{2}$ & $\mathbf{3}$ & $\mathbf{4}$ & $\mathbf{5}$ & $\mathbf{6}$ & $\mathbf{7}$ \\
$10 \mathrm{~g} / 200 \mathrm{ml}$ & 0.00 & 0.60 & 0.80 & 1.10 & 1.10 & 1.20 & 1.50 \\
$20 \mathrm{~g} / 200 \mathrm{ml}$ & 0.00 & 0.00 & 0.00 & 0.70 & 1.10 & 1.20 & 1.36 \\
$30 \mathrm{~g} / 200 \mathrm{ml}$ & 0.00 & 0.00 & 0.00 & 0.00 & 1.00 & 1.17 & 1.20 \\
$40 \mathrm{~g} / 200 \mathrm{ml}$ & 0.00 & 0.00 & 0.00 & 0.00 & 0.90 & 1.00 & 1.28 \\
$50 \mathrm{~g} / 200 \mathrm{ml}$ & 0.00 & 0.00 & 0.00 & 0.00 & 0.00 & 1.00 & 1.10 \\
\hline Control & 0.70 & 1.50 & 1.90 & 2.40 & 2.70 & 3.10 & 3.50 \\
\hline
\end{tabular}

Table 8: In vitro effect of methanolic Parkia biglobosa stem bark extract on the radial growth of Botryodiplodia theobromae (cm).

\begin{tabular}{llllllll}
\hline Concentration & \multicolumn{7}{l}{ Days of incubation and radial growth $\left(\mathbf{c m}^{2}\right)$} \\
\hline & $\mathbf{1}$ & $\mathbf{2}$ & $\mathbf{3}$ & $\mathbf{4}$ & $\mathbf{5}$ & $\mathbf{6}$ & $\mathbf{7}$ \\
$10 \mathrm{~g} / 100 \mathrm{ml}$ & 0.00 & 0.00 & 0.70 & 1.10 & 1.10 & 1.20 & 1.60 \\
$20 \mathrm{~g} / 100 \mathrm{ml}$ & 0.00 & 0.00 & 0.60 & 0.94 & 1.00 & 1.10 & 1.30 \\
$30 \mathrm{~g} / 100 \mathrm{ml}$ & 0.00 & 0.00 & 0.00 & 0.00 & 0.00 & 1.00 & 1.10 \\
$40 \mathrm{~g} / 100 \mathrm{ml}$ & 0.00 & 0.00 & 0.00 & 0.00 & 0.00 & 0.00 & 1.00 \\
$50 \mathrm{~g} / 100 \mathrm{ml}$ & 0.00 & 0.00 & 0.00 & 0.00 & 0.00 & 0.00 & 1.00 \\
\hline Control & 0.90 & 1.90 & 2.50 & 2.80 & 3.20 & 3.50 & 3.70 \\
\hline
\end{tabular}

Table 9: In vitro effect of methanolic Parkia biglobosa leaf extract on the radial growth of Aspergillus niger (cm).

\begin{tabular}{llllllll}
\hline Concentration & \multicolumn{7}{l}{ Days of incubation and radial growth $\left(\mathbf{c m}^{2}\right)$} \\
\hline & $\mathbf{1}$ & $\mathbf{2}$ & $\mathbf{3}$ & $\mathbf{4}$ & $\mathbf{5}$ & $\mathbf{6}$ & $\mathbf{7}$ \\
$10 \mathrm{~g} / 100 \mathrm{ml}$ & 0.00 & 0.40 & 0.83 & 0.99 & 1.20 & 1.30 & 1.80 \\
$20 \mathrm{~g} / 100 \mathrm{ml}$ & 0.00 & 0.00 & 0.00 & 1.00 & 1.10 & 1.20 & 1.40 \\
$30 \mathrm{~g} / 100 \mathrm{ml}$ & 0.00 & 0.00 & 0.00 & 0.00 & 0.80 & 1.20 & 1.30 \\
$40 \mathrm{~g} / 100 \mathrm{ml}$ & 0.00 & 0.00 & 0.00 & 0.00 & 0.74 & 1.00 & 1.19 \\
$50 \mathrm{~g} / 100 \mathrm{ml}$ & 0.00 & 0.00 & 0.00 & 0.00 & 0.00 & 0.80 & 1.00 \\
\hline Control & 0.60 & 1.20 & 1.90 & 2.10 & 2.40 & 2.70 & 3.10 \\
\hline
\end{tabular}

\section{DISCUSSION}

Phytochemical screening of the test plant (Parkia biglobosa) stem bark and leaf extracts used in this study was investigated to determine their exact phytochemical contents. Results of the phytochemical screening carried out revealed the presence of cardiac glycosides, reducing sugars, flavonoids, saponnins and tannins with traces of alkaloids in stem bark extracts while flavonoids, alkaloids, cardiac glycosides, saponnins, tannins and terpenoids were present in leaf extracts as 
presented in (Table 1). Phytochemicals, as compounds which occur naturally in plants, form part of plants defense mechanisms against diseases [20]. They are classified into primary and secondary, based on their activity in plant metabolism. The primary ones comprise of sugars, amino acids, proteins and chlorophyll [21], while secondary ones include the phenolic compounds such as tannins, flavonoids, alkaloids, saponins, anthraquinones, phlobatannins, proanthocyanidins, etc. [22]. These phenolic compounds have been reported to possess considerable antimicrobial properties, which is attributed to their redox properties $[23,24]$. Thus the antimicrobial properties of plants have been attributed to the presence of these secondary metabolites [25].

Seed rot disease of green bean is a major limiting factor in the production of green bean worldwide. Crop losses and cost of controlling this disease constitute a significant burden in agricultural enterprise and has serious socio-economic and environmental consequences. Consequently, there is an urgent need for effective and sustainable control of this disease. The current trend in the effective and sustainable management of plant diseases requires the use of botanical pesticides which are non-phytoxic to human and are environmentally friendly. In this study, the fungal pathogens isolated as the causative agents of seed rot disease of green bean were Botryodiplodia theobromae and Aspergillus niger. Results of this study revealed that these fungi were responsible for seed rot of green bean obtained from Akpabuyo Local Government Area of Cross River State as evidenced by the pathogenicity test. The fungal spores of these pathogens could be spread by water, ants and other insects and can land on susceptible green bean pods or seeds. The pathogen (Aspergillus niger) was reported by $[12,26]$ and [27] to cause seed rot of green bean and deterioration of other food crops. [28], reported Botryodiplodia theobromae and Aspergillus niger while [29] reported $B$. theobromae as the causative agents of fruit rot of Sour sob(Anonia muricata) and pod rot of cocoa respectively, which is in agreement with the finding of this study.

In this study, the antifungal activity of ethanolic and methanolic stem bark and leaf extracts of Parkia biglobosa was tested in vitro on fungi isolated from infected seeds of $P$. vulgaries (green bean). Results showed that the ethanolic and methanolic extracts of the stem bark and leaf of $P$. biglobosa investigated, exhibited various antifungal activities against the species of fungi isolated. The antifungal activity of the ethanolic and methanolic extracts of P. biglobosa on the isolated fungal pathogens is presented in (Tables 2-5) and (Tables 6-9) respectively. The results showed that, the ethanolic extracts had a significant $(\mathrm{P}<0.05)$ effect on the radial growth of the fungal pathogens than the methanolic extracts and the rate of antifungal activity differed from one concentration to the other. The differences in the fungitoxic potentials between these plant extracts may be attributed to the susceptibility of each of the fungal pathogens to the different plant extracts. This agrees with the results of some workers like [30] and [31]. [32], reported that some plants contain phenolic substances and essential oils, which are inhibitory to micro-organisms. The presence of these compounds in these extracts has been reported to be responsible for their antifungal properties [33]. It is noteworthy that of all the tested plant extracts (ethanolic and methanolic), ethanolic stem bark and leaf extracts of $P$. biglobosa had a more significant effect in inhibiting the redial growth of the fungal pathogens than the methanolic extracts and the level of inhibition increased with a corresponding increase in the concentration of the extracts. Complete inhibition was observed with ethanolic stem bark and leaf extracts of P. biglobosa at the higher concentrations of $40 \mathrm{~g} / 100 \mathrm{ml}$ and $50 \mathrm{~g} / 100 \mathrm{ml}$ while that of methanolic extracts was observed at $50 \mathrm{~g} / 100 \mathrm{ml}$ concentration. Also, it was observed that the ethanolic and methanolic stem bark extracts were more effective in inhibiting the redial growth of the fungal pathogens than those of the leaf extracts. The inhibitory potency of the plant extracts may be attributed to the phytochemical compounds like tannins, alkaloids, flavonoids, cardiac glycosides and saponins in them and the extraction solvents as reported by [34]. This is also in agreement with the works of [35] and [36, 16] who reported that the high potency of plant extracts containing the same bio-active compounds could be used for the control of fungal pathogens of plants. The antifungal efficacy of the stem bark and leaf extracts of $P$. biglobosa were evaluated in order to develop the cheaper methods of controlling the fungal seed rot diseases associated with $P$. vulgaries (green bean) in the field. 


\section{CONCLUSION}

The fungal pathogens isolated and identified from this study as the causative agents of seed rot of green bean obtained from the field were Botryodiplodia theobromae and Aspergillus niger. It is possible that the isolated fungal pathogens might be resident on the leaves and roots of the plant from where they were dispersed into the fruits to initiate infection spore during rainfall. Results of the in vitro antifungal assay carried out showed that the ethanolic and methanolic stem bark and leaf extracts of Parkia biglobosa were effective against the seed rot fungal pathogens of green bean at the different concentrations tested. To this effect, timely spraying of green bean crops with extracts of stem bark and leaf of P. biglobosa prepared at higher concentrations during flowering and fruiting will reduce the damaging activities of the fungal pathogens and contamination with mycotoxins and other related fungal metabolites that might be hazardous to human health.

\section{REFERENCES}

[1] A. Hayat, A. Ahmed, S. Ahmed, A. Khali, M. Gulfraz, M. Exploring the potential of Red Kidney Bean (Phaseolus vulgaris) to develop protein Based Product for food Applications. J. Anim. Plt. Sci. 24 (3) (2014) 860-868.

[2] C. S. Wortmann, Phaseolus vulgaris L. (common bean). Record from PROTA 4 U. Brink, M. and Belay, G. (Editors). PROTA (Plant Resources of Tropical Africa Ressources végétales de l'Afrique tropicale), Wageningen, Netherlands. (2006).

[3] S. Beebe, A. V. Gonzalez, J. Rengifo. Research on trace minerals in the common bean. Fd. Nut. Bull. 21(2000) 387-391.

[4] W. J. Broughton, G. Hernandez, M. Blair, S. Beebe, P. Gepts, J. Vanderleyden. Beans (Phaseolus spp): model food legume. Plt. Soi. 252 (2003) 55-128.

[5] W. Katharine. Healing foods Newlamark, MLII9D. (2002)

[6] A.F. B. Van Der Poel, I. E. Liener, P. W. Mollee, J. Huisman, J. Variations among species of animals in response to the feeding of heat-processed beans (Phaseolus vulgaris L.) on growth and organ weights of chickens and rats and digestibility for rats. Liv. Prod. Sci. 25 (1-2) (1990) 137150.

[7] S. Lopez, D. R. Davies, F. J. Giraldez, M. S. Dhamoa, J. Dijkstra, J. France, J. Assessment of nutritive value of cereal and legume straw based on chemical composition and vitro digestibility. J. Sci. Fd. Agric. 85 (9) (2005) 1550-1557.

[8] C. X. Duan, X. M. Wang, Z. D. Zhu, X. F. Wu. Testing of seedborne fungi in wheat germ-plasm conserved in the National Crop Genebank of China. Agric. Sci. 6 (2007) 682-687.

[9] K. Quenton, A. S. Theresa, F. O. Walter, P. R. Johon, V. D. W. Liana, V. D. W, S. S. Gardon. Mycoflora and fumonisin mycotoxin associated with cowpea seeds. J. Agric. Fd. Chem. 51 (2003) 2188-2191.

[10] M. D. Castillo, H. H. L. Gonzulez, E. J. Martinez, A. M. Pacin, S. L. Resnik, S. L. (2004). Mycoflora and potential for mycotoxin production of freshly harvested black beans from Argentinean main production area. Mycopathologia. Kluwer Academic Publishers, Dorderecht, Netherlands, 2004.

[11] M. Selcuk, L. Oksuz, P. Basaran. Decontamination of grains and legumes infected with Aspergillus spp. and Penicillum spp. by cold plasma treatment. Bio-res. Tech. 99 (2008) 51045109.

[12] K. V. Agrwal, B. J. Sinclair. Principles of Seed Pathology, First ed. Jai Bhawan, India, 1993.

[13] S. B. Mathur, O. Kongsdal, O. Common laboratory seed health testing methods for detecting fungi, First ed., International Seed Testing Association, India, 2003. 
[14] H. L. Barnett, B. B. Hunter. Illustrated genera of imperfect fungi 4th ed., APS Press, St. Paul Minnesota, 1998.

[15] F. M. Dugan. The identification of fungi, first ed., APS Press, St Paul Minnesota, 2006.

[16] E. J. Umana, P. I. Akwaji, A. A. Markson, S. E. Udo, S. E. Gmelina arborea Roxb: asssociated mycoflora and diseases in Cross River State, Nigeria. Glo. J. Sci. Front. Res. 15(4) (2015) 1-11.

[17] T. K. Sofowora. Medicinal plants and traditional medicine in Africa. John Wiley and Sons Incoporation, New York, 1984.

[18] G. E. Trease, W. C. Evans. Pharmacognosy, twelfth ed, Bailliers Tindal, London, UK, 1983.

[19] J. B. Harbourne. Phytochemical Methods-A Guide to Modern Techniques of Plant Analysis. Chapman and Hall, London, UK, 1983.

[20] C. O. Eleazu, K. C. Eleazu, E. Awa, S. C. Chukwuma, S. C. Comparative study of the phytochemical composition of the leaves of five Nigerian medicinal plants. J. Biotech. Pharm. Res. 3 (2012) 42-46.

[21] D. R. Krishnaiah, B. A. Sarbatly, B. A. Phytochemical antioxidants for health and medicine-A move toward nature. Biotech. Mol. Biol. Rev. 1 (2007) 97-104.

[22] C. O. Eleazu, M. A. Iroaganachi, J. O. Okoronkwo. Determination of the physicochemical composition, microbial quality and free radical scavenging activities of some commercially sold honey samples in Aba, Nigeria: 'The effect of varying colours'. Int. J. Biomed. Res. 4 (2013) 1-6.

[23] A. L. Molan, A. M. Faraj, A. M. The effects of condensed tannins extracted from different plant species on egg hatching and larval development of Teladorsagia circumcincta (Nematoda: Trichostrongylidae). Fol. Parasitol. 57 (2010) 62-68.

[24] C. Zongo. K. Savadogo, J. M. Somda, J. Koudou, A. S. Traore. In vitro evaluation of the antimicrobial and antioxidant properties of extracts from whole plant of Alternanthera pungens H.B. \& K. and leaves of Combretum sericeum G. Don. Int. J. Phytomed. 3 (2011) 182-191.

[25] G. Prakash, B. B. Hosetti. Investigation of antimicrobial properties of Dioscorea pentaphylla from mid-Western Ghats, India. Sci. Wol. 8 (2010) 91- 96.

[26] M. Schafer, P. M. Kotanen. The influence of soil moisture on losses of buried seeds to fungi. Acta Oecol. 24 (2004) 255-263.

[27] E. M. Embaby, S. Mohamed Reda, A. Mosaad, A. Abdel-Wahhab, O. Hassan, M. Asmaa, M. Mokabel. Occurrence of toxigenic fungi and micro toxin in some legume seeds. J. Agric. Technol. 9(1) (2013) $151-164$.

[28] N. A. Amusa, O. A. Ashaye, M. O. Oladapo, O. O. Kafaru. Preharvest deterioration of sour sop (Annona muricata) at Ibadan, Southwestern. Nig. Afr. J. Biotech. 2(1) (2002) 23-25.

[29] N. D. Omokolo, N. G. Tsala, P. F. Djoigoue, Changes in carbohydrate, amino acid and phenol content in cocoa pods from three clones after infection with Phytophthora Megarkaya Bra and Gift. Ann. Bot. 77(1996) 153-158.

[30] A. C. Amadioha. Fungitoxic effects of some leaf extracts against Rhizopus oryzae causing tuber rot of potato. Arc. Phytopatholf. 34 (2000) 1-9.

[31] R. N. Okigbo, I. A. Nmeka. Control of yam tuber with leaf extracts of Xylopia aethiopica and Zingiber officinale. Afr. J. Biotech. 4 (2005) 804-807.

[32] E. M. Ilondu, B. O. Ejechi, J. A. Souzey, J. A. Microbial stability of jam prepared from velvet tamarind and preserved by combined processes. Nig. J. Microbiol. 5 (2001) 93-96. 
[33] S. Ahmed, G. Stoll. Biopesticides. In: Biotechnology; Building on Farmers' Knowledge. Macmillan Education Ltd, Bunders, J., B. Haverkort and W. Hiemstra (Eds.), London, 1996, pp. 52 -79 .

[34] N. V. Chiejina, J. A. Ukeh. Efficacy of Afromomum melegueta and Zingiber officinale extracts on fungal pathogens of tomato fruit. IOSR J. Pharm. Biol. Sci. 4 (6) (2013) 13-16.

[35] A. C. Amadioha, V. I. Obi. Control of Anthracnose diseases of Cowpea by Cymbopogon cunitus and Ocimum gratissimum. Acto Phytopathol. Entomol. 85 (1999) 89-94.

[36] E. J. Umana, P. I. Akwaji, A. A. Markson, S. E. Udo, E. E. Orok. Phytochemical composition, Antimicrobial effect of Azadirachta indica and Carica papaya extracts on fungi isolated from Gmelina arborea seedlings. Int. J. Phytopathol. 03 (03) (2014) $109-115$. 